\title{
Pengaruh Ukuran Perusahaan dan Profitabilitas Terhadap Nilai Perusahaan
}

\author{
Eka Indriyani \\ STIE Panca Bhakti Palu \\ echa.mcs90@gmail.com
}

\begin{abstract}
The population in this study is all companies manufacturing food and beverage sectors in Indonesia Stock Exchange period 2011 to 2015 . The study sample as many as 16 companies were selescted using purposive sampling method with certain criteria in order to obtain in the total sample of 9 companies. Mechanical testing of the data is by using multiple linear regression with a significance level of $5 \%$ alpha. The results showed that firm size negative effect on firm value. Profitability significant effect on firm value. Simultaneously, firm size and profitability significantly influence the value of the company. The coefficient of determination shows that the influence of the independent variables on the dependent variable of $41.5 \%$ and the rest is influenced by other factors.
\end{abstract}

Key words: firm size, profitability, value of the company, the trade off theory.

\begin{abstract}
Abstrak
Populasi dalam penelitian ini adalah seluruh perusahaan manufaktur sektor makanan dan minuman di Bursa Efek Indonesia periode tahun 2011 sampai dengan 2015. Sampel penelitian sebanyak 16 perusahaan dipilih dengan menggunakan metode purposive sampling dengan kriteria tertentu sehingga diperoleh jumlah sampel sebanyak 9 perusahaan. Teknik pengujian data dengan menggunakan regresi linear berganda dengan tingkat signifikansi alpha $5 \%$. Hasil penelitian menunjukkan bahwa ukuran perusahaan berpengaruh negatif terhadap nilai perusahaan. Profitabilitas berpengaruh signifikan terhadap nilai perusahaan. Secara simultan, ukuran perusahaan dan profitabilitas berpengaruh positif terhadap nilai perusahaan. Koefisien determinasi menunjukkan bahwa pengaruh variabel independen terhadap variabel dependen sebesar 4I,5\% dan sisanya dipengaruhi oleh faktor-faktor lain.
\end{abstract}

Kata Kunci : ukuran perusahaan, profitabilitas, nilai perusahaan, teori kesenjangan

Diterima: 10 Mei 2017; Revisi: 27 Agustus 2017; Disetujui: 5 September 2017 


\section{PENDAHULUAN}

Manajer keuangan dalam sebuah perusahaan harus mampu menghimpun modal kerja agar perusahaan dapat beroperasi dengan baik sehingga apa yang menjadi tujuan bisnis perusahaan dapat tercapai secara maksimal diantaranya peningkatan laba dan likuiditas yang diharapkan. Kebutuhan modal kerja dapat dipenuhi dari berbagai sumber dan mempunyai jenis yang berbeda-beda. Modal terdiri atas ekuitas (modal sendiri) dan hutang (debt). Perbandingan antara hutang dan modal sendiri dalam struktur finansial perusahaan disebut struktur modal.

Setiap keputusan pendanaan baik internal maupun eksternal mengharuskan manajer keuangan untuk dapat mempertimbangkan manfaat dan biaya dari sumbersumber dana yang dipilih yaitu bagaimana kombinasi optimal antara pendanaan hutang dan modal sendiri (ekuitas). Kesalahan dalam menentukan struktur modal akan mempunyai dampak yang luas terutama apabila perusahaan terlalu besar dalam penggunaan hutang sehingga beban yang ditanggung perusahaan akan semakin besar. Sehingga sangat penting buat perusahaan untuk meningkatkan kegiatan produksi, pemasaran dan strategi perusahaan dalam menghadapi persaingan yang semakin kompetitif.

Menurut Brigham dan Houston (20II), menyatakan bahwa beberapa faktor penting dalam menentukan struktur modal diantaranya adalah ukuran perusahaan, struktur aktiva, leverage, tingkat pertumbuhan, profitabilitas, pajak, pengendalian, sikap pemberi pinjaman dan lembaga penilai peringkat, kondisi pasar, kondisi internal perusahaan dan fleksibilitas keuangan. Dalam teori struktur modal, trade off theory menyatakan bahwa proporsi rasio struktur modal yang optimal dapat ditemukan dengan menyeimbangkan keuntungan penggunaan hutang dengan biaya kebangkrutan dari hutang perusahaan.

Trade off theory mempunyai implikasi bahwa manajer akan berpikir antara bagaimana melakukan penghematan pajak dan mengatasi biaya kesulitan keuangan dalam penentuan struktur modal. Perusahaan-perusahaan dengan tingkat profitabilitas yang tinggu akan berusaha mengurangi pajaknya dengan meningkatkan rasio hutangnya, sehingga hutang yang semakin tinggi tentu akan mengurangi pembayaran pajak. Hal ini berlawanan dengan pecking order theory, yang mana perusahaan dengan tingkat 
profitabilitas tinggi akan menurunkan rasio hutangnya. Hal ini dikarenakan perusahaan yang memiliki profitabilitas tinggi memiliki sumber dana internal yang melimpah.

Ukuran perusahaan dianggap mempengaruhi nilai perusahaan karena semakin besar ukuran perusahaan maka semakin mudah perusahaan memperoleh sumber pendanaan yang dapat dimanfaatkan untuk mencapai tujuan perusahaan. Namun, di sisi lain akan menimbulkan hutang yang banyak karena resiko perusahaan dalam memenuhi tanggung jawabnya sangat kecil.

Perusahaan yang menghasilkan laba lebih besar cenderung mempunyai laba ditahan lebih besar sehingga dapat memenuhi kebutuhan dananya untuk melakukan perluasan usaha atau penciptaan produk baru dari sumber pendanaan internal. Semakin besar laba ditahan, semakin besar kebutuhan dana yang bersumber dari internal perusahaan sehingga akan mengurangi penggunaan dana yang bersumber dari hutang.

Nilai perusahaan diharapkan dapat digunakan seminal mungkin dengan memperhatikan jumlah modal yang diinvestasikan. Untuk perusahaan-perusahaan yang berjalan dengan baik, rasio ini dapat mengalami peningkatan dengan menunjukkan nilai pasar saham lebih besar dari nilai bukunya. Semakin tinggi rasio tersebut, perusahaan tentu semakin berhasil menciptakan nilai bagi pemegang sahamnya. Nilai perusahaan dalam penelitian ini diukur dengan menggunakan porsi Market to Book Ratio. Metode Market to Book Ratio (MBR) digunakan agar investor dalam memberikan keputusan, ada baiknya memperhatikan keberhasilan perusahaan dalam memperoleh keuntungan yang dilihat berdasarkan kegiatan operasional perusahaan.

Tujuan penelitian ini adalah untuk mengetahui signifikansi pengaruh ukuran perusahaan dan profitabilitas terhadap nilai perusahaan pada perusahaan manufaktur sektor makanan dan minuman di Bursa Efek Indonesia (BEI).

\section{KAJIAN KEPUSTAKAAN}

Modal adalah hak atau bagian yang dimiliki oleh perusahaan. Komponen modal terdiri dari setor, aigo saham, laba yang ditahan, cadangan laba dan lainnya (Kashmir, 2010). Menurut Brigham (2006) mengemukakan bahwa modal adalah jumlah dari hutang jangka panjang, saham preferen dan ekuitas saham biasa plus hutang jangka pendek yang dikenakan bunga. Dilihat dari asalnya, menurut Bambang Rianto (200I) sumber modal terdiri dari : (I) Modal yang berasal dari sumber internal adalah modal atau dana yang 
dibentuk atau dihasilkan sendiri di dalam perusahaan. Sumber internal yang dihasilkan dalam perusahaan adalah laba ditahan dan penyusutan (depresiasi). (2) Modal yang berasal dari sumber eksternal adalah modal yang dihasilkan dari luar perusahaan. Yang merupakan sumber dana eksternal adalah supplier, bank, pasar modal.

Struktur modal adalah perbandingan atau perimbangan pendanaan jangka panjang perusahaan yang ditunjukkan oleh perbandingan hutang jangka panjang terhadap modal sendiri. Pemenuhan kebetuhan dana perusahaan dari sumber modal sendiri berasal dari modal saham, laba ditahan dan cadangan. Jika dalam pendanaan perusahaan yang berasal dari modal sendiri masih memiliki kekurangan (defisit) maka perlu dipertimbangkan pendanaan perusahaan yang berasal dari luar, yaitu dari hutang (debt financing). Struktur modal yang optimal adalah gabungan ekuitas yang memaksimumkan harga saham perusahaan. Struktur modal adalah hasil atau akibat dari keputusan pendanaan (financing decision) yang intinya memilih apakah menggunakan utang atau ekuitas untuk mendanai operasi perusahaan.

Dalam membuat keputusan struktur modal, beberapa hal yang harus dipertimbangkan (Brigham dan Ehrhardt, 2005) adalah tingkat penjualan yang stabil, struktur dari asset, operating leverage, tingkat pertumbuhan, keuntungan, pajak, pengendalian, pola tingkah laku manajemen, tingkah laku atas kreditur dan peringkat agen, kondisi pasar, kondisi internal perusahaan dan fleksibilitas keuangan dan nilai pasar.

Teori struktur modal adalah teori yang menjelaskan bahwa kebijakan pendanaan perusahaan dalam menentukan bauran antara hutang dan ekuitas yang bertujuan untuk memaksimumkan nilai perusahaan. Sumber pendanaan tersebut berasal dari internal perusahaan dan eksternal perusahaan.

\section{Teori Struktur Modal Tradisional}

Menurut Darmawan Sjahrial (2008), bahwa teori struktur modal dibagi menjadi tiga kelompok besar, yaitu :

a. Pendekatan laba bersih (Net Income Approach)

Pendekatan laba bersih mengasumsikan bahwa investor mengkapitalisasi atau menilai laba perusahaan dengan tingkat kapitalisasi yang konstan dan perusahaan dapat meningkatkan jumlah hutangnya dengan tingkat biaya hutang yang konstan pula. 
b. Pendekatan laba operasi Bersih (Net Operating Income Approach)

Pendekatan laba operasi bersih berlawanan dengan pendekatan laba bersih, karena menuntut laba operasi bersih, biaya hutang bersifat tetap atau tidak berubah walaupun leverage bertambah. Dalam pendekatan laba operasi diasumsikan bahwa investor akan meminta premi karena adanya risiko keuangan akibat penambahan leverage sehingga mengakibatkan tingkat kapitalisasi akan naik secara proporsional dengan kenaikan leverage.

c. Pendekatan tradisional (Traditional Approach)

Pendekatan ini mengasumsikan bahwa tingkat leverage tertentu, risiko perusahaan tidak mengalami perubahan. Sehingga baik tingkat bunga hutang maupun tingkat kapitalisasi relatif konstan. Namun demikian setelah leverage atau rasio hutang tertentu, biaya hutang dan biaya modal sendiri meningkat.

\section{Teori Struktur Modal Modern}

a. Modigliani-Miller (MM) Theory

Teori mengenai struktur modal modern bermula pada tahun 1958, ketika Professor Franco Modigliani dan Professor Merton Miller (yang selanjutnya disebut MM) mempublikasikan artikel keuangan yang paling berpengaruh yang pernah ditulis yaitu "The Cost of Capital, Corporation Finance, and The Theory of Investment”. Menurut Modigliani dan Miller, dalam David Sukardi Kodrat dan Christian Herdinata (2009) melalui teori capital structure irrelevance menyimpulkan bahwa financial leverage tidak mempengaruhi nilai pasar perusahaan. $\mathrm{Hal}$ ini terjadi karena penggunaan hutang tidak merubah weighted average cost of capital. Artinya kenaikan penggunaan hutang tidak akan meningkatkan nilai perusahaan karena keuntungan dari biaya hutang lebih kecil ditutup dengan naiknya biaya modal sendiri.

b. Pecking Order Theory

Teori ini dikenalkan pertama kali oleh Donaldson pada tahun 1961, sedangkan penamaan pecking order theory dilakukan oleh Myers dan Majluf pada tahun 1984. Myers dan Majluf dalam Suad Husnan dan Pudjiastuti (2004). teori ini menjelaskan keputusan pendanaan yang diambil oleh perusahaan yang berbeda dengan pemikiran teori struktur modal yang telah dibahas. Pecking order theory menjelaskan mengapa perusahaan-perusahaan yang profitable umumnya meminjam 
dalam jumlah sedikit. Hal tersebut bukan disebabkan karena mereka mempunyai target debt ratio yang rendah, tetapi karena mereka memerlukan external financing yang sedikit. Perusahaan yang kurang profitable akan cenderung mempunyai hutang yang lebih besar karena dua alasan yaitu dana internal tidak cukup dan hutang merupakan sumber eksternal yang lebih disukai.

c. Trade-off Theory

Menurut trade-off theory yang diungkapkan oleh Myers (200I), "perusahaan akan berhutang sampai pada tingkat hutang tertentu, dimana penghematan pajak (tax shields) dari tambahan hutang sama dengan biaya kesulitan keuangan (financial distress)". Biaya kesulitan keuangan (financial distress) adalah biaya kebangkrutan (bankrupty costs) atau reorganization, dan biaya keagenan (agency costs) yang meningkat akibat dari turunnya kredibilitas suatu perusahaan. Trade-off theory dalam menentukan struktur modal yang optimal memasukkan beberapa faktor antara lain pajak, biaya keagenan (agency costs) dan biaya kesulitan keuangan (financial distress) tetapi tetap mempertahankan asumsi efisiensi pasar dan symmetric information sebagai imbangan dan manfaat penggunaan hutang.

d. Agency Theory

Pada dasarnya agency theory adalah teori mengenai struktur kepemilikan perusahaan yang dikelola oleh manajer bukan pemilik, berdasarkan kenyataan bahwa manajer professional bukan agen yang sempurna dari pemilik perusahaan, dengan demikian belum tentu selalu bertindak untuk kepentingan pemilik. Dengan kata lain, manajer sebagai manusia rasional, dalam pengambilan keputusan perusahaan akan memaksimalkan kepuasaan dirinya sendiri (Hidayati, et al. 200I). Jensen dan Meckling (1976) dan Weston dan Copeland (1996) menyatakan bahwa masalah keagenan berhubungan dengan penggunaan ekuitas eksternal.

e. Signalling Theory

Isyarat atau signal adalah suatu tindakan yang diambil manajemen perusahaan yang memberi petunjuk bagi investor tentang bagaimana manajemen memandang prospek perusahaan. Perusahaan dengan prospek yang menguntungkan akan mencoba menghindari penjualan saham dan mengusahakan setiap modal baru yang diperlukan dengan cara-cara lain, termasuk penggunaan hutang yang melebihi target struktur modal yang normal. Perusahaan dengan prospek yang kurang 
menguntungkan akan cenderung untuk menjual sahamnya, yang berarti mencari investor baru untuk berbagi kerugian.

f. Asymmetric Information Theory

Teori ini diajukan oleh Gordon Donaldson dari Harvard University dalam Darmawan Sjahrial (2008) tentang informasi yang tidak simetris. Asymmetric Information theory atau ketidaksamaan informasi menurut Brigham dan Houston (200I) adalah situasi dimana manajer memiliki informasi yang berbeda mengenai prospek perusahaan daripada yang dimiliki investor. Ketidaksamaan informasi ini terjadi karena pihak manajemen mempunyai informasi yang lebih baik daripada para pemodal. Dengan demikian, pihak manajemen berpikir bahwa harga saham saat ini sedang overvalue (sangat mahal).

\section{METODE}

Penelitian ini menggunakan pendekatan penelitian kuantitatif, dimana pendekatan kuantitatif ini diperlukan data numerik yang dianalisis menggunakan metode analisis regresi linear berganda dengan menggunakan program SPSS untuk menguji sejumlah hipotesis. Penelitian ini dilakukan di seluruh perusahaan manufaktur sektor makanan dan minuman yang terdaftar di Bursa Efek Indonesia periode tahun 201I- 2015 yang diperoleh dari www.idx.co.id. Jenis data yang digunakan adalah data kuantitatif, yaitu data yang diperoleh dari perusahaan manufaktur yang terdaftar di Bursa Efek Indonesia dinyatakan dalam bentuk angka-angka yang akan diolah dan dianalisa dengan metode regresi sehingga dapat terlihat hasilnya.

Dalam penelitian ini sumber data yang digunakan adalah data sekunder berupa laporan keuangan dan tahunan pada perusahaan manufaktur sektor makanan dan minuman yang terdaftar di Bursa Efek Indonesia periode tahun $201 \mathrm{I}$ sampai dengan 2015. Penentuan populasi dalam penelitian ini sebanyak 16 perusahaan. Teknik pengambilan sampel berdasarkan metode purposive sampling yaitu teknik pengambilan sampel dengan pertimbangan dan kriteria tertentu (Sugiyono, 2010). Adapun kriteria yang digunakan untuk memilih sampel adalah sebagai berikut: (I) Perusahaan manufaktur sektor makanan dan minuman yang terdaftar di Bursa Efek Indonesia sesuai dengan pengklasifikasian Indonesia capital market directory dan www.idx.co.id, jika perusahaan baru terdaftar pada tahun tersebut maka perusahaan tidak dapat dijadikan 
sampel. (2) Perusahaan manufaktur yang menerbitkan laporan keuangan tahunan secara berturut-turut dari tahun 20II-20I5. (3) Perusahaan manufaktur yang tidak mengalami kerugian selama tiga tahun berturut-turut dari tahun 20II-20I5. (4) Perusahaan yang tidak memiliki perubahan pada nilai aktiva dari tahun 20II-20I5.

Berdasarkan kriteria-kriteria yang telah ditetapkan periode tahun 2011-20I5 dapat diperoleh jumlah sampel sebagai berikut

\begin{tabular}{cll}
\multicolumn{2}{c}{ Tabel I Daftar sampel perusahaan manufaktur food \& beverage yang } \\
\multicolumn{1}{c}{$\begin{array}{c}\text { Kode } \\
\text { terdaftar di Bursa Efek Indonesia }\end{array}$} \\
\hline No & \multicolumn{1}{c}{ Perusahaan } \\
\hline I & INDF & PT. Indofood Sukses Makmur, Tbk \\
2 & STTP & PT. Siantar Top, Tbk \\
3 & ADES & PT. Akasha Wira International, Tbk \\
4 & MYOR & PT. Mayora Indah, Tbk \\
5 & SKLT & PT. Sekar Laut, Tbk \\
6 & ULTJ & PT. Ultrajaya Milk Industry and Trading Company, Tbk \\
7 & MLBI & PT. Multi Bintang Indonesia, Tbk \\
8 & CEKA & PT. Wilmar Cahaya Indonesia, Tbk \\
9 & AISA & PT. Tiga Pilar Sejahtera Food, Tbk \\
\hline Sumber : Indonesia capital market directory dan www.idx.co.id
\end{tabular}

\section{HASIL DAN PEMBAHASAN}

Analisis regresi linear berganda merupakan alat yang digunakan untuk mengetahui pengaruh variabel independen terhadap variabel dependen. Dalam konteks penelitian ini regresi linear berganda digunakan untuk menganalisis pengaruh ukuran perusahaan $\left(X_{1}\right)$ dan profitabilitas $\left(X_{2}\right)$ terhadap nilai perusahaan $(Y)$ pada perusahaan manufaktur yang terdaftar di Bursa Efek Indonesia. Analisis regresi berganda dilakukan pada tingkat signifikansi $\alpha=0,05$. Dari hasil analisis Program SPSS Wind Release 20 didapatkan hasil sebagai berikut :

Tabel 2. Hasil Analisis Regresi Berganda

\begin{tabular}{|c|c|c|c|c|c|}
\hline & \multicolumn{2}{|c|}{$\begin{array}{l}\text { Unstandardized } \\
\text { Coefficients }\end{array}$} & \multirow{2}{*}{$\begin{array}{c}\text { Standardized } \\
\text { Coefficients } \\
\text { Beta }\end{array}$} & \multirow[t]{2}{*}{$\mathrm{t}$} & \multirow[t]{2}{*}{ Sig. } \\
\hline & B & Std. Error & & & \\
\hline $\begin{array}{l}\text { (Constant) } \\
\text { Ukuran }\end{array}$ & 8,106 & 9,952 & & 0,815 & 0,420 \\
\hline Perusahaan & $-0,030$ & 0,691 & $-0,005$ & $-0,043$ & 0,966 \\
\hline Profitabilitas & $0,|5|$ & 0,031 & 1,195 & 4,895 & 0,000 \\
\hline
\end{tabular}

Sumber : Hasil Analisis Regresi Berganda (Data diolah tahun 2016) 
Pengujian secara bersama-sama (simultan) berarti semua variabel bebasnya yakni ukuran perusahaan $\left(X_{1}\right)$ dan profitabilitas $\left(X_{2}\right)$ dengan variabel tidak bebasnya yakni struktur modal diperoleh persamaan sebagai berikut :

$$
Y=8,106-0,030 X_{1}+0,151 X_{2}+\varepsilon
$$

Berdasarkan model persamaan tersebut diatas, maka dapat dijelaskan sebagai berikut :

a. Nilai konstanta sebesar 8,106 dimaknai bahwa jika ukuran perusahaan $\left(X_{1}\right)$ dan profitabilitas $\left(\mathrm{X}_{2}\right)$ diasumsikan konstan atau sama dengan nol, maka nilai perusahaan (Y) sebesar 8, 106.

b. Besarnya koefisien $X_{1}$ adalah 0,030 menunjukkan bahwa variabel ukuran perusahaan $\left(X_{1}\right)$ berpengaruh negatif terhadap nilai perusahaan (Y). Jika variabel ukuran perusahaan ditingkatkan sebesar satu satuan atau $1 \%$ maka nilai perusahaan mengalami penurunan sebesar 0,030 dengan asumsi bahwa variabel independen lain nilainya tetap. Koefisien bernilai negatif artinya terjadi hubungan tidak searah antara ukuran perusahaan dan nilai perusahaan, semakin naik ukuran perusahaan maka nilai perusahaan akan semakin menurun.

c. Besarnya koefisien $X_{2}$ adalah 0,15I menunjukkan bahwa variabel profitabilitas $\left(\mathrm{X}_{2}\right)$ berpengaruh positif terhadap nilai perusahaan (Y). Jika variabel profitabilitas ditingkatkan sebesar satu satuan atau $1 \%$ maka nilai perusahaan mengalami peningkatan sebesar 0,151 dengan asumsi bahwa variabel independen lain nilainya tetap. Koefisien bernilai positif artinya terjadi hubungan searah antara profitabilitas dan nilai perusahaan, semakin naik profitabilitas maka nilai perusahaan akan semakin meningkat.

Pengujian secara parsial dimaksudkan untuk melihat pengaruh masing-masing variabel bebas terhadap variabel tidak bebasnya sebagai berikut :

a. Untuk ukuran perusahaan $\left(X_{1}\right)$ tingkat signifikansinya sebesar $5 \%$ dengan nilai signifikansi t sebesar 0,966. Hal ini berarti bahwa sig $t>\alpha$ yaitu 0,966 $>0,05$. 
Kemudian nilai $t_{\text {hitung }}$ sebesar $-0,043$ dan $t_{\text {tabel }}$ sebesar I,683 $(d f=n-k-I$ atau $d f=45-$ $3-I=4 I)$ menunjukkan bahwa $t_{\text {hitung }}<t_{\text {tabel }}$ yaitu $-0,043<I, 683$. Dari hasil ini menunjukkan bahwa $\mathrm{H}_{0}$ diterima dan $\mathrm{H}_{\mathrm{a}}$ ditolak. Hal ini berarti variabel ukuran perusahaan secara parsial berpengaruh negatif dan tidak signifikan terhadap nilai perusahaan.

b. Untuk profitabilitas $\left(X_{2}\right)$ tingkat signifikansinya sebesar $5 \%$ dengan nilai signifikansi $t$ sebesar 0,000. Hal ini berarti bahwa sig $t<\alpha$ yaitu $0,000<0,05$. Kemudian nilai $t_{\text {hitung }}$ sebesar 4,895 dan $t_{\text {tabel }}$ sebesar $I, 683(d f=n-k-I$ atau $d f=45-3-I=4 I)$ menunjukkan bahwa $t_{\text {hitung }}>t_{\text {tabel }}$ yaitu 4,895 $>$ I,683. Dari hasil ini menunjukkan bahwa $\mathrm{H}_{0}$ ditolak dan $\mathrm{H}_{\mathrm{a}}$ diterima. $\mathrm{Hal}$ ini berarti variabel profitabilitas secara parsial berpengaruh positif dan signifikan terhadap nilai perusahaan.

Tabel 3. Hasil Uji F

\begin{tabular}{ccc}
\hline & $F$ & Sig. \\
\hline$X_{1}$ dan $X_{2}$ & 9,691 & $0,000^{a}$ \\
\hline \multicolumn{2}{c}{ Sumber : Hasil Uji F (Data diolah tahun 2016) }
\end{tabular}

Berdasarkan hasil analisis regresi pada tabel diatas menunjukkan bahwa nilai signifikansi $F$ sebesar 0,000. Hal ini berarti bahwa sig $F<\alpha$ yaitu 0,000<0,05. Kemudian nilai $F_{\text {hitung }}$ sebesar 9,69I dan $F_{\text {tabel }}$ sebesar 2,833 $(\mathrm{df}=\mathrm{n}-\mathrm{k}-\mathrm{I}$ atau df $=45-3-\mathrm{I}=$ 4l) menunjukkan bahwa $F_{\text {hitung }}>F_{\text {tabel }}$ yaitu 9,69I $>2,833$. Dari hasil ini menunjukkan bahwa $\mathrm{H}_{0}$ ditolak dan $\mathrm{H}_{\mathrm{a}}$ diterima. $\mathrm{Hal}$ ini berarti variabel ukuran perusahaan dan profitabilitas secara simultan berpengaruh positif dan signifikan terhadap nilai perusahaan.

Perhitungan regresi untuk nilai $\mathrm{R}$ (koefisien korelasi) untuk melihat hubungan antara variabel independen dengan variabel dependen. Besarnya nilai koefisien korelasi (R) sebesar 0,644 menunjukkan bahwa hubungan variabel independen yaitu ukuran perusahaan $\left(X_{1}\right)$ dan profitabilitas $\left(X_{2}\right)$ terhadap variabel dependen yaitu nilai perusahaan (Y) sebesar 0,644. Jika dalam prosentase diperoleh hasil sebesar $64,4 \%$ menunjukkan bahwa hubungan antara variabel independen terhadap variabel dependen kuat dan searah. 
Tabel 5. Hasil Uji Koefisien Determinasi $\left(\mathbf{R}^{2}\right)$

\begin{tabular}{ccccc}
\hline Model & $\mathrm{R}$ & $\begin{array}{c}\mathrm{R} \text { square } \\
\left(\mathrm{R}^{2}\right)\end{array}$ & $\begin{array}{c}\text { Adjusted } \mathrm{R} \text { square (Adj } \\
\left.\mathrm{R}^{2}\right)\end{array}$ & $\begin{array}{c}\text { Std. Error of The } \\
\text { Estimate }\end{array}$ \\
\hline $\mathrm{I}$ & $0,644^{\mathrm{a}}$ & 0,415 & 0,372 & 7,28186 \\
\hline
\end{tabular}

Sumber : Hasil Uji Koefisien Determinasi (Data diolah tahun 2016)

Besarnya pengaruh variabel independen secara bersama-sama terhadap variabel dependen dapat dilihat dari besarnya koefisen determinasi $\left(R^{2}\right)$. Nilai koefisen determinasi $\left(R^{2}\right)$ berada pada interval $0 \leq R^{2} \leq I$. Nilai koefisen determinasi $\left(R^{2}\right)$ pada penelitian ini sebesar 0,4I5 menunjukkan bahwa pengaruh variabel independen yaitu ukuran perusahaan $\left(X_{1}\right)$ dan profitabilitas $\left(X_{2}\right)$ terhadap variabel dependen yaitu nilai perusahaan (Y) sebesar 0,4I5. Jika dalam prosentase diperoleh hasil sebesar 4I,5\% menunjukkan bahwa pengaruh antara variabel independen terhadap variabel dependen dalam penelitian ini sebesar $41,5 \%$ dan sisanya sebesar $58,5 \%$ dipengaruhi oleh faktor lain yang tidak dijelaskan dalam penelitian ini.

\section{Pembahasan}

Berdasarkan hasil analisis regresi linear berganda yang diperoleh melalui uji $t$, hasilnya adalah nilai signifikan $t>a$ yaitu $0,966>0,05$. Kemudian nilai $t_{\text {hitung }}$ sebesar $-0,043$ dan $t_{\text {tabel }}$ sebesar I,683 menunjukkan bahwa $t_{\text {hitung }}<$ $t_{\text {tabel }}$ yaitu $-0,043<1,683$. Dari hasil ini menunjukkan bahwa $H_{0}$ diterima dan $H_{a}$ ditolak. Hal ini menunjukkan bahwa pengaruh ukuran perusahaan tidak signifikan terhadap nilai perusahaan. Artinya nilai perusahaan tidak dipengaruhi oleh ukuran perusahaan. Jadi hipotesis pertama yang diajukan peneliti tidak diterima.

Hal ini tidak sejalan dengan teori bahwa semakin besar ukuran suatu perusahaan maka akan semakin mudah perusahaan tersebut memperoleh sumber pendanaan yang kemudian dapat dimanfaatkan oleh pihak manajemen untuk meningkatkan nilai perusahaan. Kemungkinan yang dapat terjadi dari hasil penelitian ini bahwa perusahaan lebih cenderung menyukai pendanaan internal dibandingkan dari hutang, sehingga ukuran perusahaan tidak memiliki pengaruh terhadap penggunaan sumber dana eksernal. 
Variabel profitabilitas berpengaruh positif dan signifikan terhadap nilai perusahaan. Hal ini menunjukkan bahwa profitabilitas berbanding lurus dengan nilai perusahaan. Jika profitabilitas mengalami peningkatan maka nilai perusahaan juga akan mengalami peningkatan, begitu pula sebaliknya. Jadi hipotesis ketiga yang diajukan peneliti diterima. Hal ini sesuai dengan teori bahwa profitabilitas yang tinggi mencerminkan kemampuan perusahaan dalam menghasilkan keuntungan yang tinggi bagi pemegang saham. Dengan rasio profitabilitas yang tinggi yang dimiliki perusahaan akan menarik minat investor untuk menanamkan modalnya di perusahaan. Tingginya minat investor untuk menanamkan modalnya pada perusahaan dengan profitabilitas yang tinggi akan meningkatkan harga saham sehingga akan meningkatkan nilai perusahaan.

Penelitian ini mendukung pecking order theory karena perusahaan yang menghasilkan laba lebih besar cenderung mempunyai laba ditahan lebih besar sehingga dapat memenuhi kebutuhan dananya dari sumber internal perusahaan. Semakin besar laba ditahan, semakin besar kebutuhan dananya dipenuhi dari dalam perusahaan (dana internal) sehingga mengurangi penggunaan dana dari hutang (dana eksternal).

\section{SIMPULAN}

Berdasarkan hasil penelitian dengan menggunakan metode analisis regresi linear berganda, dapat disimpulkan yakni: I) Ukuran perusahaan tidak berpengaruh signifikan terhadap nilai perusahaan, 2) Profitabilitas berbanding lurus terhadap nilai perusahaan nilai perusahaan. Semakin tinggi profitabilitas maka semakin meningkat pula nilai perusahaan, begitu pula sebaliknya, 3) Ukuran perusahaan (firm size), dan profitabilitas berbanding lurus terhadap nilai perusahaan. Artinya jika ukuran perusahaan dan profitabilitas meningkat maka nilai perusahaan juga akan meningkat, 4) Hasil koefisien determinasi $R^{2}$ sebesar 0,415 menunjukkan bahwa pengaruh ukuran perusahaan dan profitabilitas terhadap nilai perusahaan sebesar $41,5 \%$. 


\section{PUSTAKA ACUAN}

Apriweni, Prima dkk. 20Il. Pengaruh Rasio Profitabilitas, Rasio Leverage, Rasio Likuiditas, dan Economic Value Added terhadap Harga Saham. Jurnal Manajemen Keuangan Vol. I No. I: 35-47.

Arifin, Zaenal. 2005. Teori Keuangan dan Pasar Modal. Yogyakarta: Ekonisia.

Atmaja, Lukas Setia. 2008. Teori dan Praktik Manajemen Keuangan. Yogyakarta: ANDI.

Bae, S.C., T.H. Kwong, dan J.W. Lee. 2007. Related And Unrelated Corporate Diversification And Firm Value: Evidence from Korean Business Groups. Strategic Management Journal.

Brealey, M., dan Marcus. 2007. Dasar-dasar Manajemen Keuangan Perusahaan. Jakarta: PT. Erlangga.

Brigham, Eugene F., dan Joel F. Houston. 200I. Manajemen Keuangan. Jakarta: Erlangga.

Brigham, Eugene F., dan Joel F. Houston. 2006. Dasar-dasar Manajemen Keuangan. Jakarta: Salemba Empat.

Chatoth, P. K., dan M.D. Olsen. 2007. The Effect of Enviroment Risk, Corporate Strategy and Capital Structure on Firm Performance: An Empirical Investigation of Restaurant Firm. International Journal of Hospitality Management 26: $502-516$.

Chen, Jian dan Roger Strange. 2006. The Determinants of Capital Structure: Evidence from Chinese Listed Companies. Journal of Economic Change and Restructring. 38:11-35.

Deemsomsak, R., Krishna, P., \& Giola, P. 2004. The Determinants of Capital Structure: Evidance from the Asia Pasific Region. Journal of Multinational Financial Management, 14.

Ferdiansyah, Muhammad Syahril \& Isnurhadi. 2013. Faktor-Faktor yang Mempengaruhi Struktur Modal Pada Perusahaan Pertambangan yang Terdaftar di Bursa Efek Indonesia. Jurnal Manajemen \& Bisnis Sriwijaya Vol. I I No. 2.

Ghozali, Imam. 20II. Aplikasi Analisis Multivariat dengan Program SPSS 19.0. Semarang: BP Universitas Diponegoro. 
Gill. Amarjit. et. al. 2009. The Determinants of Capital Structure in the Service Industry:Evidence from United States.. The Open Business Journal. 2: 48-53.

Gitman, Lawrence J. 2003. Principles of Managerial Finance. NJ: Addison Wesley.

Graham. John dan Harvey. Campbell. 2002. How Do CFOs Make Capital Budgeting and Capital Structure Decisions. Journal of Applied Corporate Finance.

Hackbarth. Dirk. Miao. Jianjun dan Morellec Erwan. 2006. Capital Structure Credit Risk and Macroeconomics Conditions. Journal of Financial Economics. 82. 519550.

Hatfield. Gay. B. Cheng. Louis T.W. dan Davidson Wallace. N. 1994. The Determination of Optimal Capital Structure: The Effect of Form and Industry Debt Ratios on Market Value. Journal of Financial and Strategic Decisions. Vol. 7.3.

Hasnawati, Sri. 2005. Implikasi Keputusan Investasi, Pendanaan dan Dividen Terhadap Nilai Perusahaan Publik di Bursa Efek Jakarta. Usahawan. No. 09/ Th XXXIX, September 2005.

Helfert, E.A. 1997. Teknik Analisis Keuangan. Jakarta: Erlangga.

Husnan, Suad. 2000. Manajemen Keuangan Teori dan Penerapan (Keputusan Jangka Panjang). Yogyakarta: BPFE.

Husnan, Suad., dan E. Pudjiastuti. 2004. Dasar-Dasar Manajemen Keuangan. Yogyakarta: UUP AMP YKPN.

Joni, Lina. 2010. Faktor-Faktor yang Mempengaruhi Struktur Modal. Jurnal Bisnis dan Akuntansi. Vol. 12 No. 2.

Kasmir, 20I0. Pengantar Manajemen Keuangan. Jakarta: Kencana.

Kisgen, Darren J. 2006. Credit Ratings and Capital Structure. Journal of Finance. Vol LXI (3).

Kodrat, David Sukardi dan Herdinata, Christian. 2009. Manajemen Keuangan based on Empirical Research. Yogyakarta: Graha Ilmu.

Munawir, S. 200I. Analisa Laporan Keuangan. Edisi 10. Yogyakarta: Liberti.

Myers, S. C. 1984. The Capital Structure Puzzle. Journal of Finance 39 (3) pp. 575-592. 
Priyatno, Duwi. 2010. Paham Analisa Statistik Data dengan SPSS. Yogyakarta: MediaKom.

R. Agus Sartono dan Ragil Sriharto. 1999. Faktor-Faktor Penentu Struktur Modal Perusahaan Manufaktur di Indonesia. Sinergi. Vol 2: I75-I88.

Riyanto, Bambang. 200I. Dasar-Dasar Pembelanjaan Perusahaan. Yogyakarta: BPFE.

Ross. Stephen. A. Randolph. Westerfield. Jeffrey. Jaffe. 2008. Corporate Finance. Boston: Irwin/McGraw-Hill.

Salvatore, Dominick. 2005. Ekonomi Manajerial dalam Perekonomian Global. Jakarta: Salemba Empat.

Santoso, Singgih. 2012. Buku Latihan SPSS Statistik Parametrik. Jakarta: PT. Alex Media Komputindo.

Sartono, R. Agus. 200I. Teori \& Aplikasi Manajemen Keuangan. Yogyakarta: BPFE.

Sheikh, N.A., dan Zongjun, W. 20I I. Determinants of Capital Structure An Empirical Study of Firms in Manufacturing Industry of Pakistan. Journal of Managerial Finance. Vol. 37 No. 2: II7-I33.

Sjahrial, Darmawan. 2008. Manajemen Keuangan, Edisi Kedua. Jakarta: Mitra Wacana Media:.

Soliha, E., dan Taswan. 2002. Pengaruh Kebijakan Hutang Terhadap Nilai Perusahaan Serta Beberapa Faktor Yang Mempengaruhinya. Jurnal Bisnis dan Ekonomi. September 2002.

Sugihen, S. G. 2003. Pengaruh Struktur Modal Terhadap Produktivitas Aktiva, Kinerja Keuangan Serta Nilai Perusahaan Industri Manufaktur Terbuka di Indonesia. Disertasi.

Sugiyono. 2010. Metode Penelitian Bisnis (Pendekatan Kuantitatif, Kualitatif dan R\&D). Alfabeta: Bandung.

Suliyanto. 201I. Ekonometrika Terapan: Teori \& Aplikasi dengan SPSS. Yogyakarta: Andi.

Tiro, Muhammad Arif. 20I I. Analisis Korelasi dan Regresi, Edisi Ketiga. Makasar: Andira Publisher.

Titman, S., dan Robert, W. 1998. The Determinants of Capital Structure Choice. Journal of Finance. Vol. 42: I-19. 
Umar, Husein. 2000. Metode Penelitian untuk Skripsi dan Tesis Bisnis. Jakarta: PT. Raja Grafindo Persada.

Van Horne, James C. \& John M. Wachowicz, JR. 1997. Prinsip-Prinsip Manajemen Keuangan. Jakarta: Salemba Empat:.

Weston, J. F., Eugene, F. B. 2004. Dasar-Dasar Manajemen Keuangan. Jakarta: Erlangga.

Wild. John. J. Subramanyam. K. R. \& Halsey. Robert.F. 2005. Analisis Laporan Keuangan. Jakarta: Salemba Empat. 